\title{
PERKEMBANGAN KOMERSIALISASI PERTANIAN DI INDONESIA DAN PROYEKSINYA 2005-2050
}

\author{
Rachmini Saparita \\ Peneliti pada UPT B2P TTG LIPI ${ }^{1}$
}

\begin{abstract}
This article identified the growth commercial agriculture through diversification of crops to predict the process of agricultural transformation in Indonesia. The result showed that the growth of commercial agriculture was varied. Some provinces, such as Jakarta, West Java, North and West Sumatera, Riau, Kalimantan, Midle and South Sulawesi, which had low index, commercialization worked well. The economic pattern of their farmer changed from subsistence to commercial. Agricultural development in those provinces entered to the growth and advanced stages of agricultural transformation. However, others provinces, which had high index, commercial agriculture worked poorly. For all provinces outside Java islands, the cause of those high indexes were predicted by several factors, such as lack of infrastructure, remote areas, and other limitations, so that business accesses to outside areas were not run well. For all provinces inside Java islands, the cause was predicted by the excessive of subsistence agriculture, so that commercial agriculture was delayed, while other areas were suited for various food crops type. From that situation it could be concluded that agricultural development was not spread equally for every province in Indonesia. Since agricultural development policies were such as the existing strategies, the growth of commercial agriculture were predicted would not affect the increase of farmer's income, because the growth was not caused by transformation of agricultural economic pattern from subsistence to commercial, but was caused by agriculture household enlargement. Consequently, the government should apply land reform policy immediately.
\end{abstract}

Key words: agricultural diversification, agricultural commercialization, agricultural transformation, and agricultural development

\section{PENDAHULUAN}

Komersialisasi pertanian merupakan sarana untuk meningkatkan pendapatan petani, ketika produksi yang hasilkan (hasil panen) melebihi kebutuhan dasar hidupnya. Hal tersebut dapat dipenuhi apabila luas lahan memadai, dengan dukungan produktivitas lahan yang baik. Komersialisasi pertanian merupakan tanda berlangsungnya proses transformasi pertanian, yaitu proses perubahan pola ekonomi pertanian dari subsisten ke komersial. Semakin berjalan transformasi pertanian, semakin berkembanglah komersialisasinya, dan semakin sejahteralah petani. Timmer (1997) menjelaskan bahwa terjadinya proses transformasi pertanian karena berlangsungnya pembangunan pertanian.

Pembangunan pertanian di Indonesia telah berjalan sejak lama, khususnya sejak berlangsungnya pemerintahan Indonesia. Selama pembangunan pertanian berjalan, fenomena 
yang teramati adalah semakin besar kesenjangan pendapatan terjadi, baik antara petani 'kecil' (buruh tani) dengan petani 'besar' (pemilik lahan di atas 1 ha), maupun antara masyarakat di sektor pertanian dan nonpertanian. BPS (1999) melaporkan pendapatan petani 'besar' pada tahun 1976, dua kali lebih tinggi dari pendapatan buruh taninya. Tetapi pada tahun 1998 , perbedaannya menjadi tiga kali. Tahun 1980 pendapatan per kapita golongan atas di sektor nonpertanian lima kali lebih besar dari pendapatan golongan bawah pertanian (buruh tani). Pada tahun 1998 perbedaan mereka menjadi sepuluh kali lipat.

Untuk melihat penyebab kondisi tersebut terjadi, maka proses transformasi pertanian yang merepresentasikan hasil pembangunan pertanian ditelaah melalui penelaahan perkembangan komersialisasi pertanian. Dengan diketahuinya perkembangan komersialisasi pertanian, maka dapat diduga keberlangsungan proses transformasi pertanian, apakah telah berada pada taraf maju, dengan taraf komersialisasi yang tinggi, ataukah masih dalam kondisi tradisional, dengan taraf komersialisasi yang rendah, ataukah mempunyai pola yang beragam. Proyeksi perkembangan komersialisasi diperlukan untuk memberi rekomendasi kebijakan pembangunan pertanian ke depan agar hasil pembangunan dapat mensejahterakan kehidupan masyarakat tani Indonesia.

\section{METODE PENELITIAN}

Untuk melihat perkembangan komersialisasi pertanian yang telah terjadi, penelitian menggunakan data sekunder dari BPS ${ }^{1}$ untuk periode 1960-2004. Pengolahan data dilakukan dengan metode statistika deskriptif. Tahun 1960 diasumsikan merupakan permulaan pembangunan pertanian oleh Pemerintah Indonesia 'modern'. Hal ini terindikasi dengan adanya peningkatan kontribusi ekonomi (peningkatan PDB) (BPS, 1973). Komoditas tanaman pangan padi dan palawija (padi, jagung, singkong, ubi jalar, kacang tanah dan kedelai) dipergunakan sebagai wakil sektor pertanian, karena kontribusinya selama 1960-2004 masih di atas $60 \%$. Wilayah yang dimodelkan adalah wilayah negara Indonesia dengan 26 propinsi (di luar Timor Timur) yang berlaku pada masa Orde Baru, karena data di BPS sampai 2002 masih terkompilasi seperti itu, sementara data 2003 dan 2004 disesuaikan dengan katagori propinsi sebelumnya (26).

1. Jl. KS. Tubun no 5 Subang. Telp. 0260-411478; Fax:0260-411239, HP: 08122366075. saparita@lipi.go.id; saparita@subang-java.com 
Mengacu pada penjelasan Timmer (1997), bahwa indeks diversifikasi pertanian dapat dipilih sebagai indikator perkembangan komersialisasi, maka perkembangan diversifikasi tanaman di seluruh wilayah Indonesia menjadi bahan kajian. Indeks (derajat) diversifikasi pertanian di 26 propinsi tersebut dihitung menggunakan rumus indeks diversifikasi $\mathrm{D} \equiv 1-\mathrm{H} ; \mathrm{D}$ merupakan ukuran penghitungan karakteristik pergiliran tanaman, $\mathrm{H}$ merupakan indeks Hirshman-Herfindahl, dan indeks diversifikasi pertanian di tingkat propinsi (tingkat semi-mikro) dihitung menggunakan rumus:

$$
\mathrm{D}_{\mathrm{ht}}=1-\mathrm{H}_{\mathrm{ht}}=1-\sum\left(\frac{\mathrm{A}_{\text {hit }}}{\sum_{\mathrm{i}} \mathrm{A}_{\text {hit }}}\right)^{2}
$$

$D_{\text {ht }}$ merupakan indeks diversifikasi pertanian di suatu propinsi tertentu, yaitu derajat penanaman tanaman tertentu di propinsi tersebut. Ahit merupakan luas lahan dari tanaman i di propinsi h pada tahun $t$ (Kurosaki, 2001, 2002a,2002b). Indeks diversifikasi pertanian yang semakin menurun menurut Timmer menandakan terjadinya spesialisasi pertanian karena kegiatan komersialisasi pertanian berkembang (Timmer, 1997).

Untuk melihat proyeksi perkembangan komersialisasi di masa yang akan datang, penelitian menggunakan model transformasi pertanian yang telah dikembangkan Saparita (2004) dan telah teruji kesahihannya. Perkembangan komersialsiasi pertanian direpresentasikan oleh perkembangan pertanian (rumah tangga petani) komersial. Proyeksi perkembangan komersialisasi pertanian akan dilihat sampai tahun 2050, setelah pembangunan pertanian berjalan selama 90 tahun. Pengambilan tahun 2050 didasarkan pada asumsi bahwa pembangunan pertanian di Indonesia akan mengantarkan pada proses transformasi pertanian dengan mulus setelah berjalan 90 tahun. Hal ini didasarkan pada sejarah berlangsungnya proses transformasi pertanian di negara maju seperti Inggris (sekitar 1750-1875); Amerika (sekitar 18201960); Jepang (sekitar 1880-1970); Taiwan dan Korea (sekitar 1912- 1970) (Hayami \&Ruttan: 1979; Johnston \& Kilby: 1975; Yamada \& Hayami: 1979; Lee \& Chen: 1979; Ban: 1979; Kuncoro: 1997).

\section{HASIL DAN PEMBAHASAN}

\section{Perkembangan Diversifikasi Pertanian, 1960-2004}


Hasil perhitungan $D_{\text {ht }}$ untuk ke 26 propinsi dan juga secara nasional $\left(D_{t}\right)$ dituangkan pada Gambar 1-6. Gambar-gambar tersebut memperlihatkan perkembangan diversifikasi pertanian di tingkat propinsi dan di tingkat nasional (Indonesia) selama pembangunan pertanian berlangsung.

Derajat diversifikasi pertanian di propinsi-propinsi yang ada di wilayah Sumatera bagian barat dan utara (empat propinsi) menunjukkan pola perkembangan yang beragam. Meskipun demikian empat propinsi tersebut (Gambar 1) memperlihatkan diversifikasi pertanian mereka dalam kurun waktu 42 tahun masih di bawah diversifikasi tingkat nasional. Nangro Aceh Darussalam (Aceh) pada awalnya mempunyai indeks diversifikasi yang paling rendah jika dibandingkan dengan tiga propinsi lain di bagian utara dan barat Sumatera, kemudian meningkat sampai yang paling tinggi. Peningkatan indeks diversifikasi di Aceh khususnya (juga di propinsi lain) menunjukan adanya perkembangan jenis komoditi pertanian yang di tanam, karena setiap daerah memerlukan keragaman tanaman, sehingga indeks diversifikasi meningkat. Indeks diversifikasi pertanian di Aceh kemudian menurun kembali (sampai 0,2735) pada periode 1991 . 2004. Hal ini menunjukkan bahwa telah terjadi perluasan wilayah komersialisasi, sehingga terjadi konsentrasi tanaman tertentu di wilayah ini, karena kebutuhan tanaman lain dapat dipenuhi oleh wilayah yang lain melalui kegiatan komersialisasi pertanian antar wilayah. Nilai rata-rata, nilai minimun dan nilai maksimum dari indeks diversifikasi pertanian di empat propinsi tersebut pada Tabel 1.

Berbeda dengan Aceh, indeks diversifikasi pertanian di Sumatera Utara, Sumatera Barat, dan Riau menunjukkan indeks yang secara umum mempunyai pola yang agak stabil. Peningkatan dan penuruan pada periode- periode tertentu terjadi, namun tidak secara drastis berubah (Gambar 1). Indeks diversifikasi ke empat propinsi di bawah derajat diversifikasi tingkat nasional. Hal ini menunjukkan bahwa telah terjadi komersialisasi pertanian dengan baik. Setiap wilayah berkonsentrasi menanam tanaman yang unggul di daerahnya.

Tabel 1. Indeks diversifikasi pertanian di Sumatera Bagian Barat \& Utara, 1960-2004

\begin{tabular}{llllll}
\hline \multirow{2}{*}{ Propinsi } & Rata-rata & \multicolumn{2}{c}{ Maksimum } & \multicolumn{2}{c}{ Minimum } \\
\cline { 2 - 6 } & & Indeks & Tahun & Indeks & Tahun \\
\hline NAD (Aceh) & 0,2923 & 0,5780 & 1990 & 0,0687 & 1970 \\
Sumatera Utara & 0,3320 & 0,4600 & 1998 & 0,2346 & 1970 \\
Sumatera Barat & 0,1709 & 0,2413 & 1987 & 0,1144 & 1980 \\
R i a u & 0,2785 & 0,3972 & 2002 & 0,1637 & 1976 \\
\hline
\end{tabular}




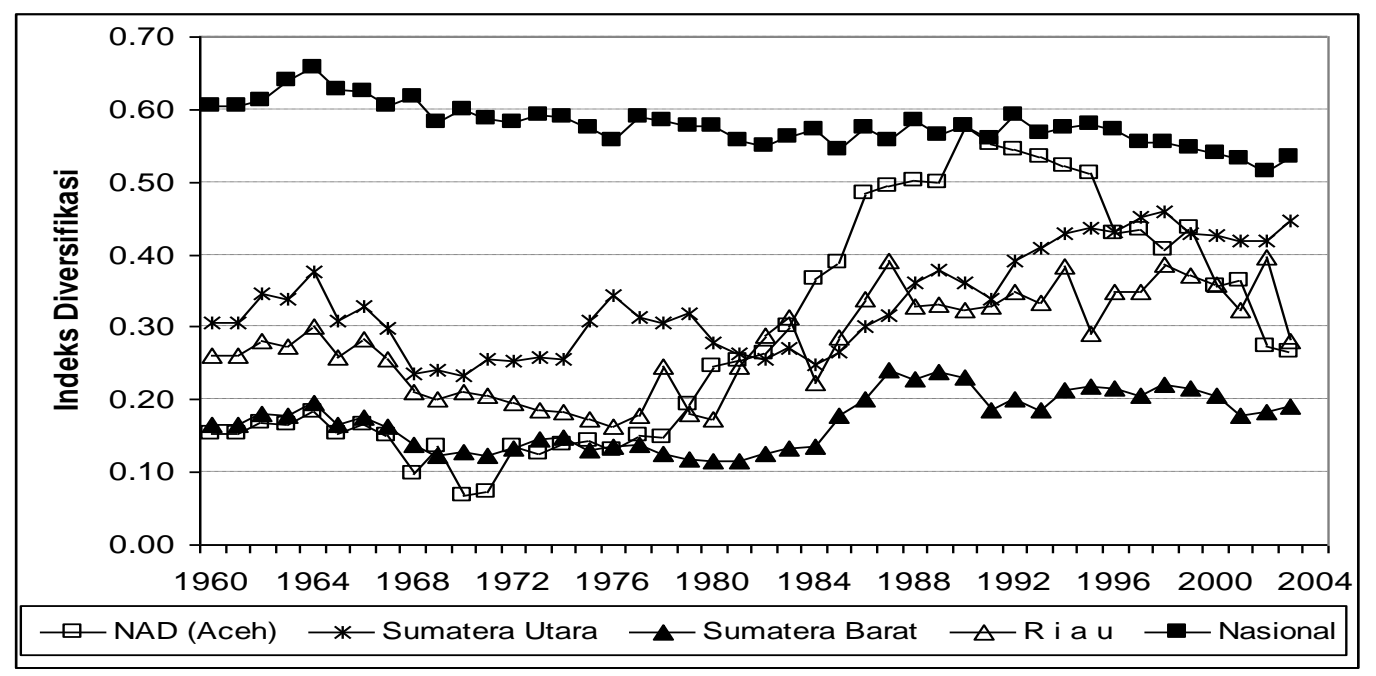

Gambar 1. Perkembangan diversifikasi pertanian di Sumatera Bagian Barat \& Utara, 1960-2004

Pola perkembangan diversifikasi propinsi lain di wilayah Sumatera (Gambar 2), terlihat sedikit berbeda jika dibandingkan dengan pola perkembangan empat propinsi lainnya di Sumatera ini (Gambar 1). Secara umum indeks diversifikasi ke empat propinsi di wilayah Sumatera bagian selatan ini meningkat, khususnya sejak 1980-an. Peningkatan terbesar terlihat pada propinsi Bengkulu, sementara Lampung dan Sumatera Selatan meskipun ada kenaikan derajat diversifikasi, tetapi berfluktuasi setiap tahunnya. Secara rata-rata per tahun (Tabel 2), indeks diversifikasi dari urutan terbesar sampai terkecil berturut-turut adalah Lampung (062); Bengkulu (0,32); Sumatera Selatan $(0,23)$; dan Jambi $(0,18)$.

Tabel 2. Indeks diversifikasi pertanian di Sumatera Bagian Selatan, 1960-2004

\begin{tabular}{lccccc}
\hline Propinsi & Rata-rata & \multicolumn{2}{c}{ Maksimum } & \multicolumn{2}{c}{ Minimum } \\
\cline { 2 - 6 } & & Indeks & Tahun & Indeks & Tahun \\
\hline J a m b i & 0,1793 & 0,3546 & 1999 & 0,0666 & 1979 \\
Sumatera Selatan & 0,2317 & 0,3612 & 1997 & 0,1295 & 1972 \\
Bengkulu & 0,3223 & 0,5903 & 1997 & 0,1320 & 1971 \\
Lampung & 0,6224 & 0,7135 & 1992 & 0,5052 & 1969 \\
\hline
\end{tabular}




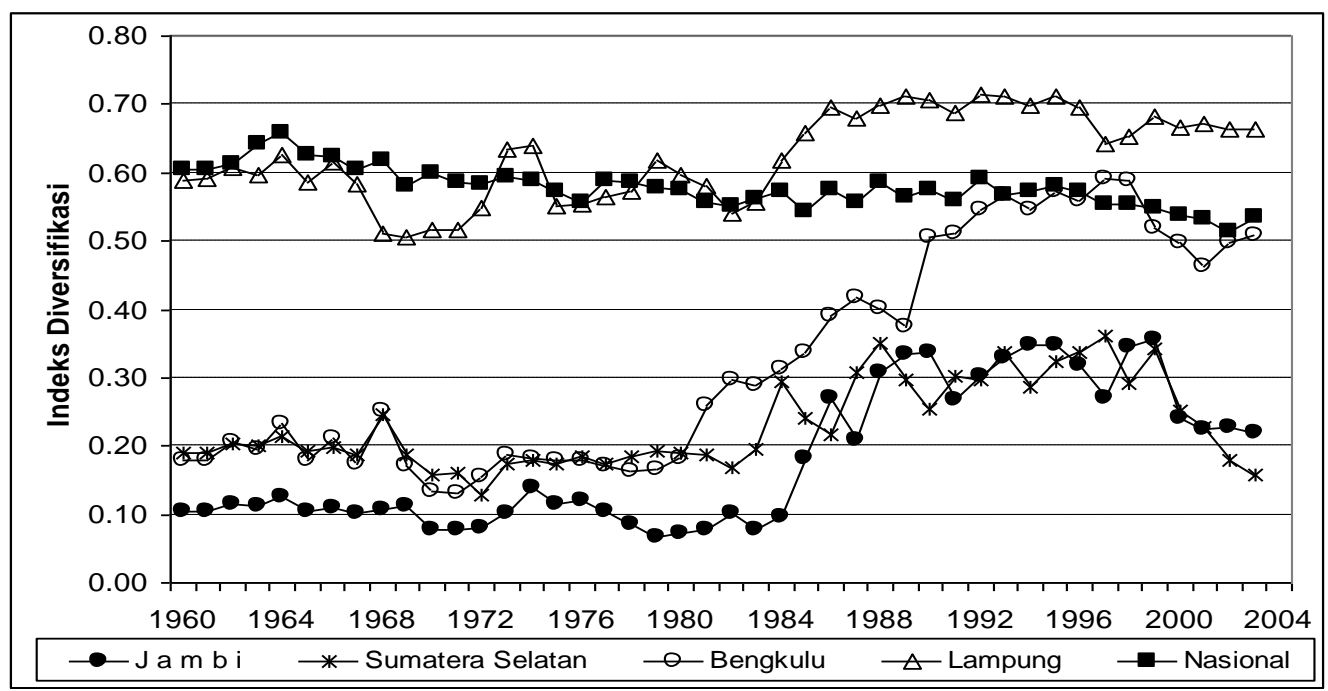

Gambar 2. Perkembangan diversifikasi pertanian di Sumatera Bagian Selatan, 1960-2004

Selama 1960-1980, Lampung mempunyai derajat diversifikasi hampir sama dengan derajat diversifikasi tingkat nasional, sedangkan pada periode setelah 1980-an, derajat diversifikasi di Lampung lebih tinggi dari derajat diversifikasi tingkat nasional. Kondisi tersebut mengidikasikan bahwa sejak 1980-an ke-empat propinsi menanam banyak tanaman pangan, meskipun ketiga propinsi di luar Lampung masih mempunyai indeks diversifikasi di bawah indeks tingkat nasional. Hal yang memicu peningkatan diversifikasi di empat propinsi tersebut belum dapat ditelusur. Kemungkinan adanya program transmigrasi dari Pulau Jawa menjadi pemicu beragamnya tanaman pangan di sediakan di wilayah masing-masing.

Perkembangan diversifikasi pertanian di Jawa berbeda untuk setiap propinsi. Beberapa propinsi mempunyai indeks pertanian di atas indeks nasional, dan beberapa lagi mempunyai indeks di bawah tingkat nasional (Gambar 3). Secara rata-rata per tahun, indeks pertanian dengan urutan tertinggi sampai terendah (Tabel 3), masing-masing adalah Daerah Istimewa Yogyakarta $(0,74)$; Jawa Timur $(0,7)$; Jawa Tengah $(0,63)$; Jawa Barat $(0,35)$; dan Daerah Khusus Ibu Kota Jakarta $(0,23)$.

Indeks diversifikasi pertanian di DKI Jakarta mempunyai pola yang sangat berbeda jika dibandingkan dengan seluruh propinsi yang ada di Indonesia. Pada tahap awal (1960-1969), DKI Jakarta mempunyai indeks yang cukup tinggi, dengan nilai yang hampir sama dengan indeks tingkat nasional. Namun setelah 1969 penurunan secara drastis terjadi, dalam waktu delapan tahun mampu menurun sampai ke angka 0,08. Setelah itu indeks pertanian di DKI Jakarta masih mengalami penurunan sampai ke titik terendah 0,03 pada tahun 1992. Pada tahun 2002-2004 
indeks diversifikasi pertanian di DKI Jakarta sebesar 0,1. Kondisi ini menggambarkan pertanian di Jakarta sangat spesifik. Kebutuhan komoditi pertanian dapat dipasok dari berbagai daerah. Komersialisasi telah berlangsung baik dan lancar.

Tabel 3. Indeks diversifikasi pertanian di Jawa, 1960-2004

\begin{tabular}{llllll}
\hline Propinsi & Rata-rata & Maksimum & \multicolumn{3}{c}{ Minimum } \\
\cline { 2 - 6 } & & Indeks & Tahun & Indeks & Tahun \\
\hline DKI Jakarta & 0,2290 & 0,6582 & 1964 & 0,0311 & 1992 \\
Jawa Barat & 0,3529 & 0,4831 & 1964 & 0,2818 & 2001 \\
Jawa Tengah & 0,6323 & 0,6958 & 1964 & 0,5536 & 2002 \\
DI Yogyakarta & 0,7413 & 0,7713 & 1992 & 0,7018 & 1969 \\
Jawa Timur & 0,7001 & 0,7457 & 1962 & 0,6455 & 2002 \\
\hline
\end{tabular}

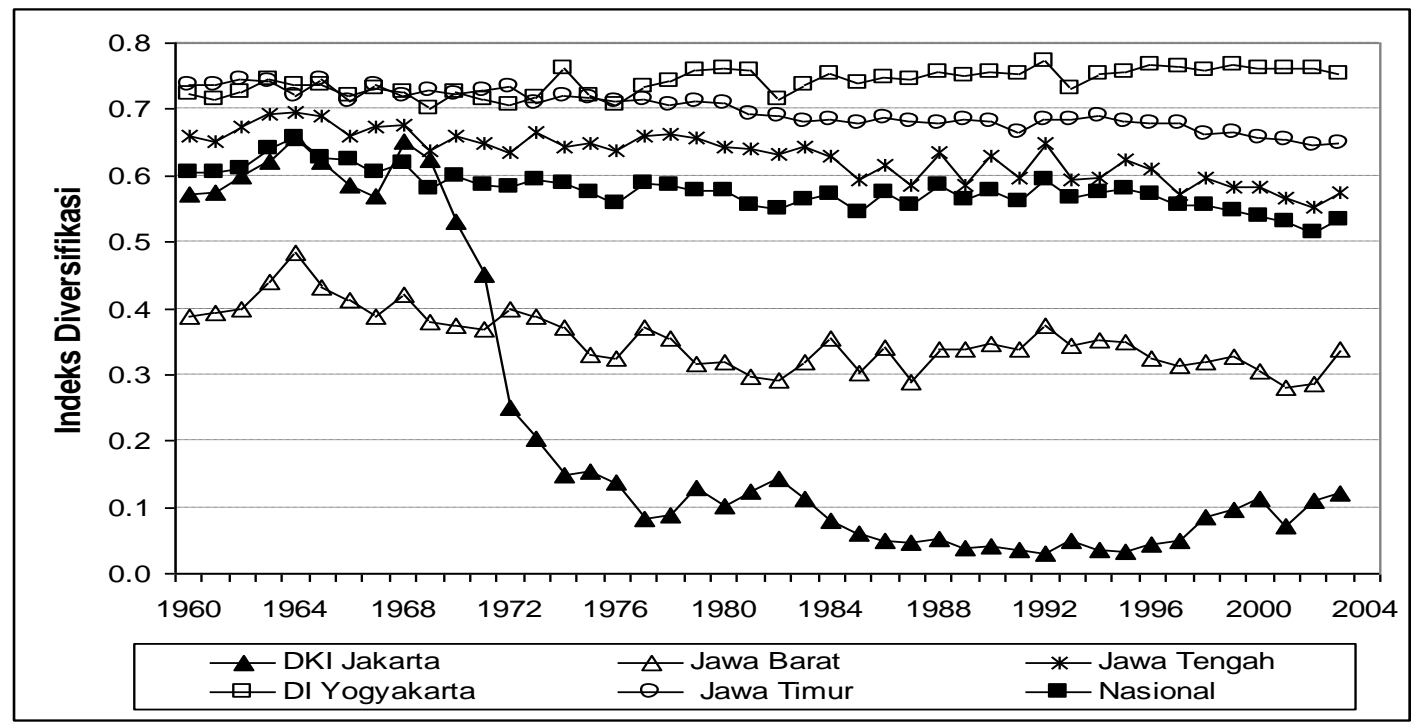

Gambar 3. Perkembangan diversifikasi pertanian di Jawa, 1960-2004

Indeks diversifikasi pertanian di Jawa Barat sejak 1960 sampai 2004 cenderung mengalami penurunan, meskipun dalam perjalanannya mengalami beberapa kenaikan dan penurunan (berfluktiasi). Selama 42 tahun indeks diversifikasi di Jawa Barat berada selalu di bawah indeks tingkat nasional (Gambar 3). Indeks terkecil dicapai pada tahun 2001 dengan nilai 0,28, dan indeks tertinggi dicapai pada tahun 1964 dengan nilai 0,48 (Tabel 3). Apabila mengacu pada teori transformasi pertanian dari Timmer (1997), maka Jawa Barat merupakan salah satu propinsi yang sesuai dengan teorinya. Semakin berjalannya pembangunan pertanian, semakin menurunnya diversifikasi pertanian di tingkat wilayah yang lebih rendah.

Berbeda dengan Jawa Barat, Indeks diversifikasi di Jawa Tengah, juga DI Yogyakarta dan Jawa Timur, selalu berada di atas indeks nasional selama 42 tahun pengamatan (Gambar 3). 
Secara umum indeks di Jawa Tengah dan Jawa Timur cenderung menurun, namun untuk Yogyakarta terlihat semakin meningkat. Berbagai kemungkinan melatar-belakangi kondisi propinsi-propinsi yang mempunyai indeks pertanian lebih besar dari indeks pertanian tingkat nasional, padahal di ketiga wilayah (DI Yogyakarta, Jawa Tengah dan Jawa Timur) merupakan wilayah dengan sarana transportasi yang telah tergolong baik, yang tingkat komersialisasi pertaniannya tergolong lancar dan maju. Tetapi tidak terspesialisasinya tanaman di ketiga propinsi tersebut tidak berarti karena tidak berkembangnya komersialisasi pertanian, tetapi kemungkinan ketiga daerah memang cocok untuk ditanami berbagai jenis tanaman pangan, atau spesialisasi terjadi di tingkat petani individu. Beragamnya komoditi yang ditanam oleh petani yang sudah melaksanakan spesialisasi tanaman dapat saja terjadi. Sayangnya hal tersebut tidak dapat dipantau oleh analisis pada penelitian ini.

Pola perkembangan diversifikasi pertanian di Bali, Nusa Tenggara Barat (NTB), Nusa Tenggara Timur (NTT), Maluku dan Papua cukup berbeda antar satu propinsi dengan propinsi yang lainnya (Gambar 4). Hal ini terlihat dari nilai rata-rata, minimum dan maksimum selama 42 tahun pada Tabel 4. Pola perkembangan diversifikasi pertanian di propinsi Bali dan NTB mengikuti pola perkembangan di tingkat nasional, bahkan Bali dan pola nasional mempunyai nilai yang hampir sama. Seperti halnya di Jawa, Bali mempunyai tanah pertanian yang cukup subur untuk ditanami berbagai tanaman, sementara kemungkinan NTB mempunyai derajat diversifikasi pertanian yang tinggi karena sulitnya transportasi di pedalaman maka wilayah harus meyediakan berbagai tanaman yang diperlukan penduduk.

Tabel 4. Indeks diversifikasi pertanian di Bali, NTB, NTT, Maluku dan Papua, 1960-2004

\begin{tabular}{llllll}
\hline Propinsi & Rata-rata & Maksimum & \multicolumn{3}{c}{ Minimum } \\
\cline { 2 - 5 } & & Indeks & Tahun & Indeks & Tahun \\
\hline J a m b i & 0,6752 & 0,7598 & 2002 & 0,5243 & 1978 \\
Sumatera Selatan & 0,1097 & 0,1920 & 1990 & 0,0363 & 1980 \\
Bengkulu & 0,6808 & 0,7265 & 1990 & 0,4241 & 1988 \\
Lampung & 0,6079 & 0,7310 & 1996 & 0,4591 & 1985 \\
\hline & 0,7376 & 0,8134 & 1999 & 0,5222 & 1978 \\
\hline
\end{tabular}




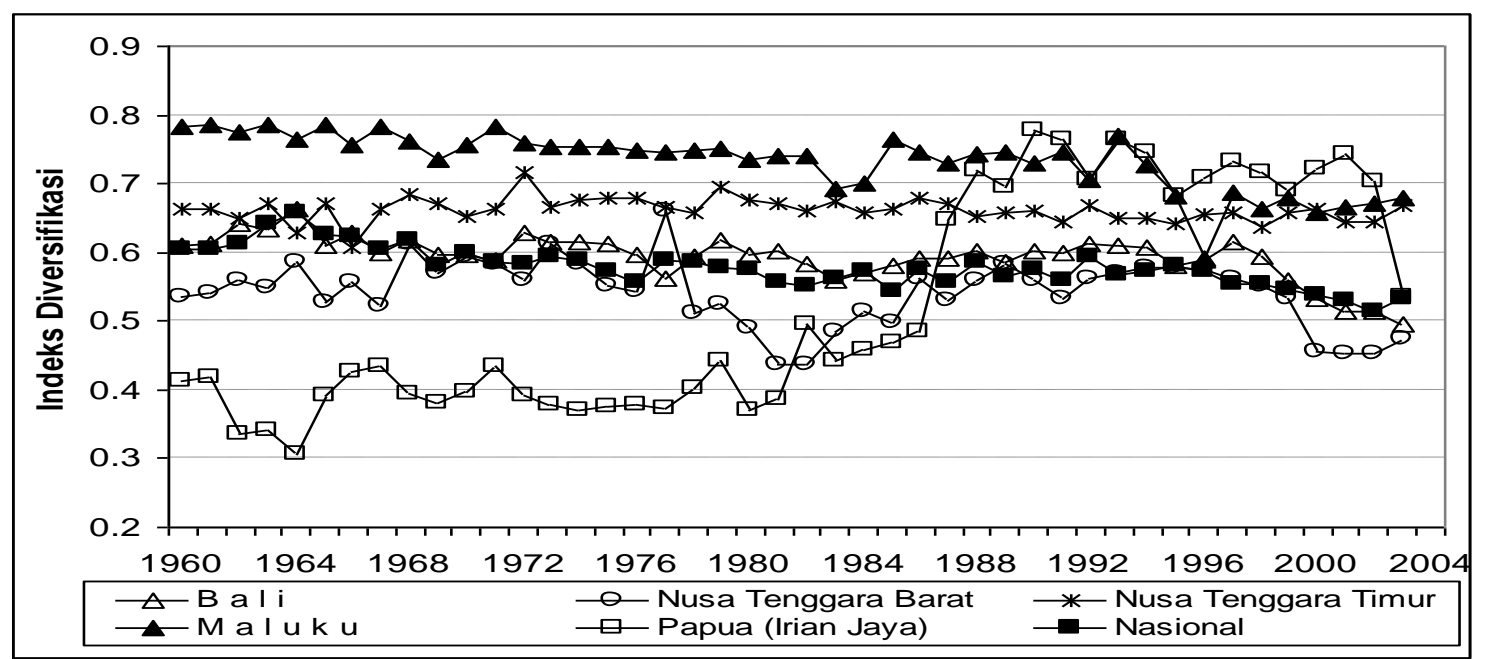

Gambar 4. Perkembangan diversifikasi pertanian di Bali, NTB, NTT, Maluku dan Papua, 19602004.

Diversifikasi pertanian di Maluku dan NTT mempunyai pola yang menurun namun senantiasa berada di atas indeks nasional. Hal ini mengindikasikan bahwa pada wilayah tersebut pertanian sedang mulai berjalan ke arah spesialisasi. Derajat diversifikasi pertanian di Maluku lebih tinggi dari tingkat nasional. Kemungkinan karena sulitnya sarana transportasi, maka wilayah tersebut harus menyediakan berbagai kebutuhan komoditi pangan penduduk. Berbeda dengan propinsi lain, Papua pada mulanya mempunyai indeks di bawah indeks nasional, namun sejak 1980an indeks pertaniannya meningkat jauh mulai melebihi indeks tingkat nasional. Hal ini mencerminkan terjadinya perkembangan jenis komoditi yang ditanam penduduk di wilayahnya. Karena sarana transportasni masih terbatas, maka Papua harus menyediakan berbagai komoditi keperluan penduduknya.

Indeks diversifikasi pertanian di Kalimantan tergolong kecil jika dibandingkan dengan propinsi lainnya di Indonesia. Empat propinsi yang ada di Kalimantan berada di bawah indeks diversifikasi nasionalnya (Gambar 5). Hal yang menarik adalah hampir semua propinsi tersebut mempunyai pola perkembangan indeks diversifikasi yang sama, meskipun puncak tertinggi dan terendah indeks pertanian mereka berbeda-beda (Tabel 5). Penyebab kondisi tersebut belum dapat dijelaskan secara terperinci. Kemungkinan memang sudah terspesilasisasi di seluruh propinsi. 
Tabel 5. Indeks diversifikasi pertanian di Kalimantan,1960-2004

\begin{tabular}{llllll}
\hline Propinsi & Rata-rata & Maksimum & \multicolumn{3}{c}{ Minimum } \\
\cline { 2 - 6 } & & Indeks & Tahun & Indeks & Tahun \\
\hline Kalimantan Barat & 0,2196 & 0,3147 & 1964 & 0,1322 & 1982 \\
Kalimantan Tengah & 0,2011 & 0,3026 & 1999 & 0,1255 & 1993 \\
Kalimantan Selatan & 0,1417 & 0,2564 & 1996 & 0,0540 & 1974 \\
Kalimantan Timur & 0,2393 & 0,3888 & 1985 & 0,1249 & 1976 \\
\hline
\end{tabular}

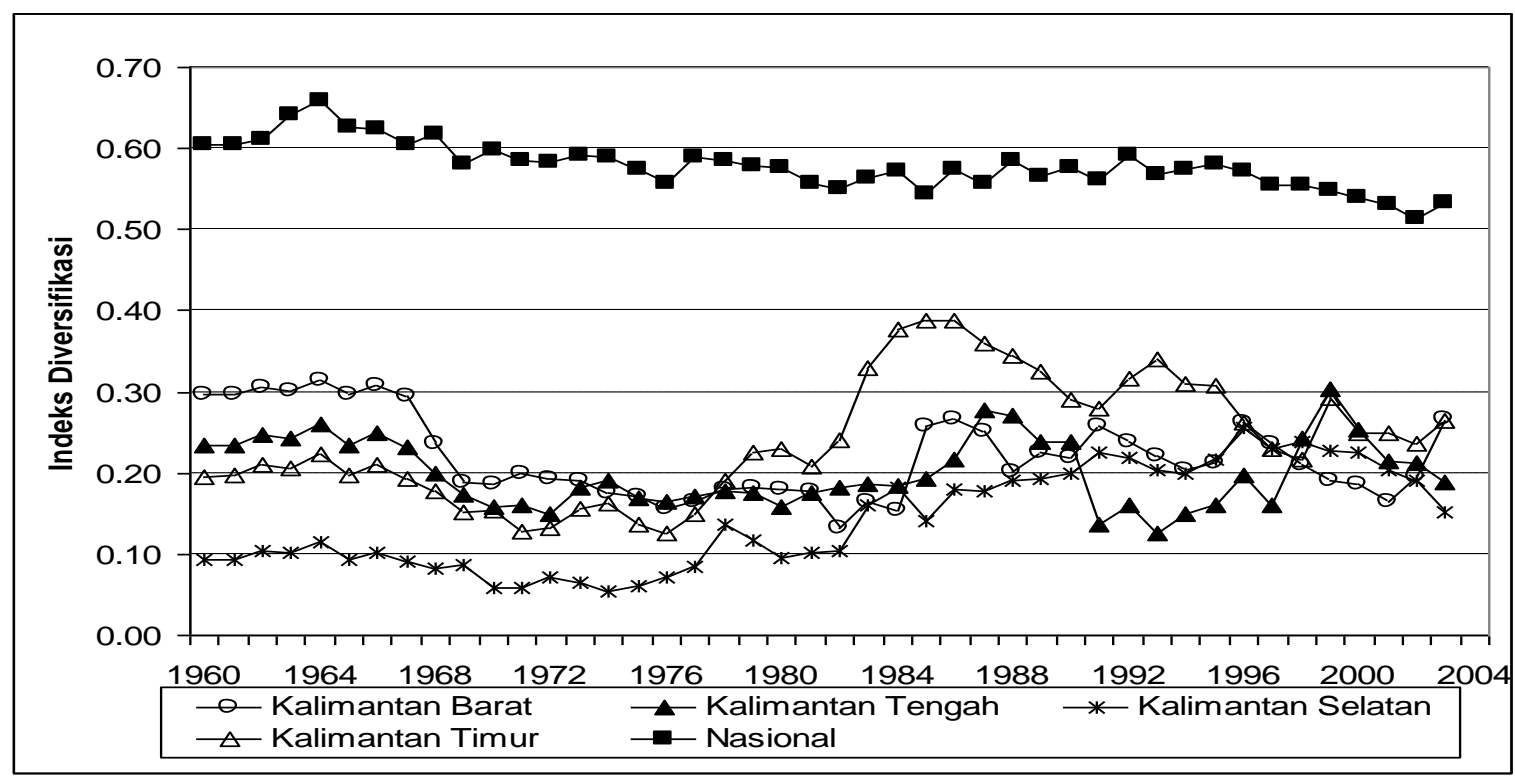

Gambar 5. Perkembangan diversifikasi pertanian di Kalimantan, 1960-2004

Indeks diversifikasi pertanian di Sulawesi terbagi dua kelompok: kelompok pertama, dua propinsi (Sulawesi Tengah dan Sulawesi Selatan) mempunyai indeks diversifikasi di bawah indeks diversifikasi tingkat nasional, sedangkan kelompok ke dua (Sulawesi Utara dan Sulawesi Tenggara) mempunyai indeks diversifikasi di atas indeks diversifikasi pertanian tingkat nasional (Gambar 6 dan Tabel 6). Ke-empat propinsi di Sulawesi mempunyai indeks diversifikasi pertanian yang berfluktuasi. Kelompok pertama (Sulawesi Tengah dan Sulawesi Selatan) mempunyai kecenderungan indeks yang menurun, meskipun melalui fluktuasi yang cukup tajam. Sementara kelompok ke dua (Sulawesi Utara dan Sulawesi Tenggara) mempunyai indeks yang cenderung meningkat terlebih dahulu, dan pada tahun 1990-an indeks pertanian kelompok ke dua ini terlihat menurun. Sulawesi Tengah dan Sulawesi Selatan mempunyai indeks rata-rata 0,47 dan 0,52 per tahun, semetara Sulawesi Utara dan Sulawesi Tenggara masing-masing mempunyai indeks ratarata 0,65 dan 0,66 per tahun. 
Tabel 6. Indeks diversifikasi pertanian di Sulawesi, 1960-2004

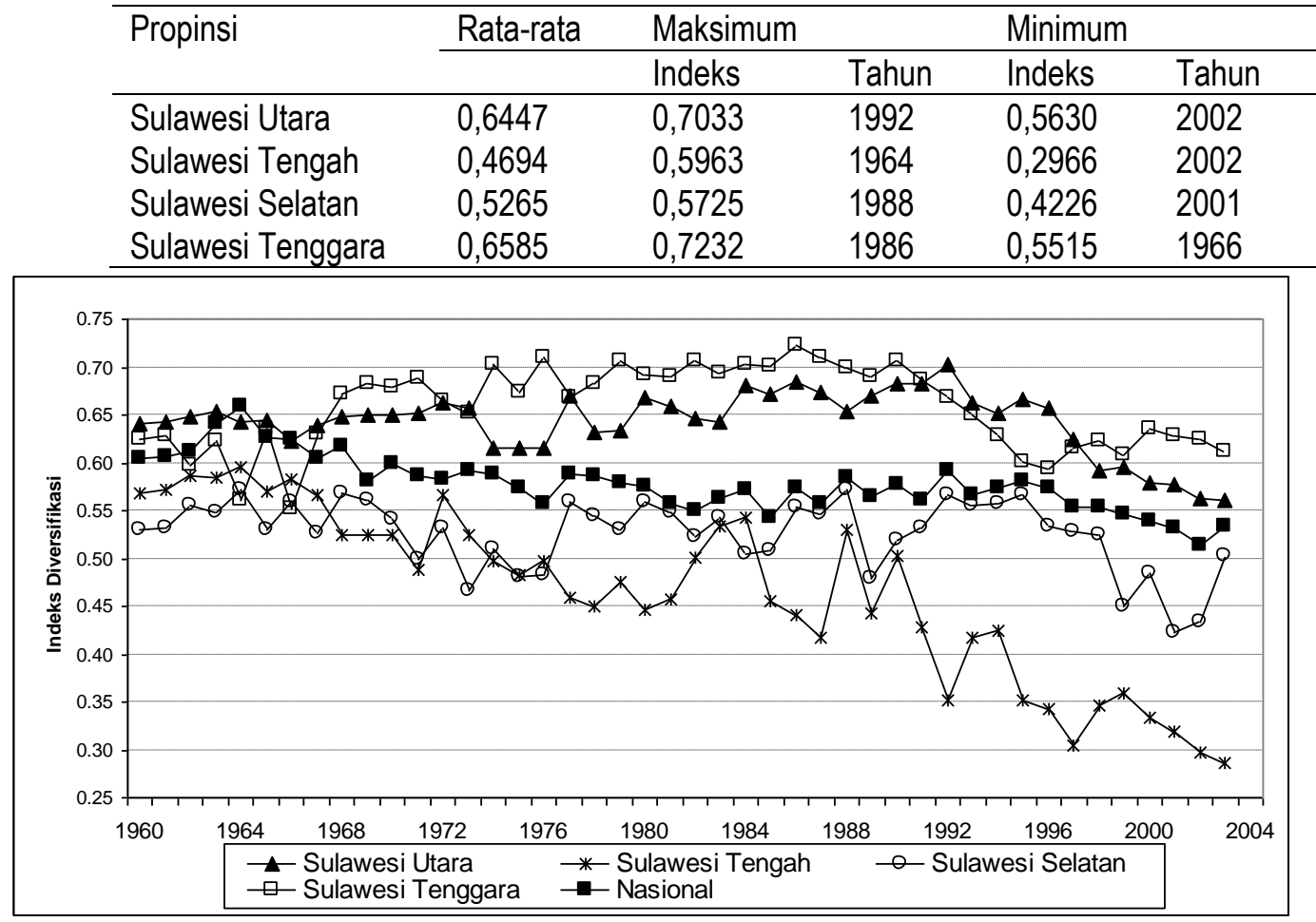

Gambar 6. Perkembangan diversifikasi pertanian di Sulawesi, 1960-2004

\section{Proses Transformasi Pertanian di Indonesia, 1960-2004}

Apabila melihat hasil perkembangan diversifikasi pertanian di seluruh wilayah Indonesia yang sangat beragam seperti di atas, maka dapat tarik gambaran bahwa proses transformasi pertanian yang terjadi di Indonesia tidak serempak terjadi. Hal ini didasarkan pada perkembangan komersialisasi pertanian yang berlangsung. Di sebagian propinsi seperti DKI Jakarta, Jawa Barat, Sumatera Utara, Sumatera Barat, Riau, seluruh Kalimantan, Sulawesi Tengah dan Selatan, yang mempunyai derajat diversifikasi pertanian yang rendah dan menurun, yaitu lebih kecil dari indeks diversifikasi pertanian di tingkat nasional, komersialisasi pertanian telah berjalan baik. Pola ekonomi para petaninya telah bergeser dari pertanian subsisten ke pertanian komersial. Hal ini mengacu pada penjelasan Timmer (1997) bahwa derajat diversifikasi yang menurun menjadi lebih kecil menandakan berkembangnya pasar pertanian, yang memungkinkan petani memilih komoditi yang mempunyai keunggulan komparatif dan berkontribusi pada peningkatan produktivitas secara makro sehingga keanekaragaman hasil produksi di tingkat individu (mikro) menurun (terjadi spesialisasi). Karena pasar pedesaan berkembang, maka terjadilah komersialisasi pertanian. Saat itu usahatani di tingkat mikro (individu), terspesialisasi pada penanaman komoditi pertanian 
tertentu (komersial). Semakin ekonomi tumbuh, derajat diversifikasi di tingkat mikro terlihat semakin rendah (spesialisasi semakin tinggi), sehingga keaneka-ragaman hasil produksi lebih sedikit jika dibandingkan dengan di tingkat yang lebih tinggi (makro) Perbedaan derajat diversifikasi antara tingkat mikro dan makro tersebut menjadi cukup nyata. Spesialisasi di tingkat mikro (regional dan petani individu) karena komersialisasi pertanian ditambahkan oleh Pingali (1997) dapat memicu pertumbuhan pendapatan. Dan ketika pendapatan meningkat, terjadilah pertumbuhan ekonomi, para petani semakin menspesialisasikan produksi lagi (Kurosaki, 2002b). Rosegrant dan Hazell (2000) menjelaskan bahwa spesialisasi dianggap dapat lebih cepat merespon harga pasar dan kualitas produk. Huffman dan Evenson (1997) menambahkan bahwa spesialisasi tanaman yang dilakukan pertanian individu dapat meningkatnya pertumbuhan produktivitas pertanian.

Pada sebagian wilayah lain, derajat diversifikasi pertanian cenderung tinggi dan masih meningkat, menandakan bahwa transformasi pertanian baru berproses. Hal ini mengacu pada penjelasana Timmer (1997), bahwa pada tahap awal (I), derajat diversifikasi cenderung sama dengan tingkat nasional. Hal ini disebabkan setiap wilayah menanam tanaman pangan yang dibutuhkan masyarakat sekitarnya. Pada tahap ini pertumbuhan ekonomi belum terlihat. Pasar produk pertanian belum berkembang baik, sedangkan pasar yang ada hanya pasar lokal. Setelah tahap awal dilewati, transformasi pertanian memasuki tahap perkembangan (Tahap II), yang ditandai dengan berkembangnya pasar pertanian, seperti yang terjadi pada propinsi yang mempunyai derajat diversifikasi yang rendah dan menurun.

Jika kembali mengamati hasil perhitungan derajat diversifikasi di seluruh wilayah Indonesia tadi, maka proses transformasi pertanian di Indonesia secara umum diduga baru memasuki tahap awal (I) dan perkembangan awal (II), belum memasuki tahap perkembangan lanjut (Tahap III), kecuali DKI Jaya. Di DKI Jaya, proses transformasi diduga telah memasuki tahap III, yang apabila mengacu pada penjelasan Timmer, tahap III ini ditandai dengan peningkatan kembali pada derajat diversifikasi nasional, sebab adanya peningkatan permintaan konsumsi pangan yang beragam, yang berhubungan dengan kontribusi jasa yang semakin tinggi dalam produk pangan jadi. Pada tahap III ini derajat diversifikasi di tingkat usahatani individu (dalam penelitian ini di tingkat wilayah), menjadi menurun lagi, karena prinsip keunggulan komparatif yang terus diacu. Sejak 1972 derajat diversifikasi di DKI Jaya menurun secara drastis, setelah berkembang pasar pertanian dari luar DKI yang dapat memasok kebutuhan komoditi pertanian di DKI. 
Apabila mengacu kembali pada penjelasan Timmer (1997), bahwa secara umum semakin transformasi berjalan, semakin tumbuh perekonomian di sektor pertanian, dan pada akhirnya proses transformasi pertanian sejalan dengan pertumbuhan perekonomian negara, begitu pula menurut Todaro (2000) bahwa usahatani yang terspesialisasi merupakan ciri dari tahap akhir proses transformasi pertanian, karena pola pertanian menjadi efisien dan produksi pertanian dapat memenuhi kebutuhan pangan nasional, maka hasil pembangunan di Indonesia secara umum belum adil dan merata, karena hasil yang sangat beragam yang menyebabkan terjadinya kesenjangan pendapatan. Pembangunan pertanian ternyata menyebabkan semakin beragamnya hasil yang diraih, yang tercermin dari proses transformasi pertanian yang terjadi. Oleh karena itu perbedaan pendapatan masyarakat semakin besar, baik antar sektor (pertanian dan nonpertanian) maupun antar kelompok (masyarakat 'bawah' dengan masyarakat 'atas'). Untuk itu pemerintah perlu meninjau ulang kebijakan yang telah dilaksanakan, apakah telah memberi perbaikan bagi masyarakat bawah atau tidak.

\section{Proyeksi Perkembangan Komersialisasi Pertanian: 2005-2050}

Untuk melihat proyeksi perkembangan komersialisasi pertanian, maka model transformasi pertanian yang dikembangkan Saparita (2004) dijalankan kembali. Dengan asumsi kebijakan pembangunan pertanian masih seperti kebijakan yang sekarang dilaksanakan, maka prediksi perkembangan komersialisasi pertanian di Indonesia sampai 2050 diduga mengalami peningkatan. Peningkatan tersebut diduga terjadi karena adanya peningkatan jumlah rumah tangga pertanian (Gambar 7), bukan karena banyaknya peralihan pertanian subsisten ke komersial sebab apabila dilihat Gambar 8, terlihat bahwa luas lahan garapan pertanian secara rata-rata mengalami penurunan. Jadi meskipun secara jumlah rumah tangga mengalami peningkatan, namun secara rata-rata luas lahan garapan mereka semakin menurun, sampai pada ambang batas ukuran minimum pertanian komersial (2004). Dari gambaran seperti itu maka diduga proses transforamsi pertanian tidak berjalan mulus meskipun pembangunan sudah berjalan 90 tahun. Proses perubahan pola pertanian dari subsisten ke komersial tidak berlangsung lancar, sehingga peningkatan pendapatan rumah tangga pertanian tidak mulus. 


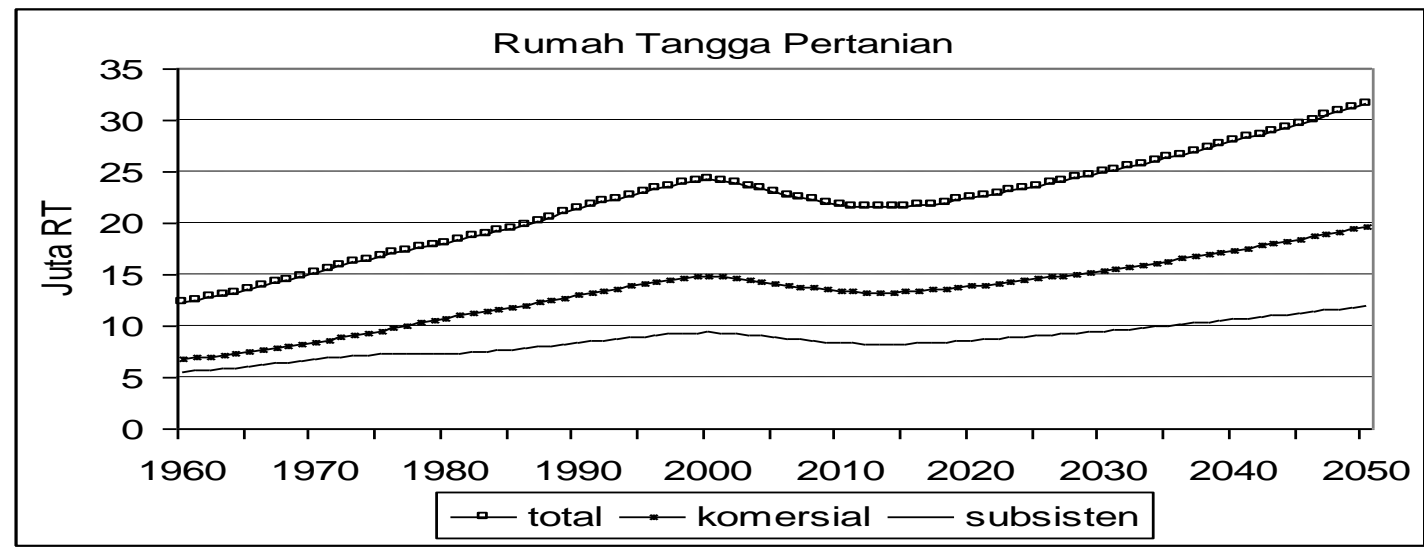

Gambar 7. Prediksi perkembangan pertanian subsisten dan komersial di Indonesia

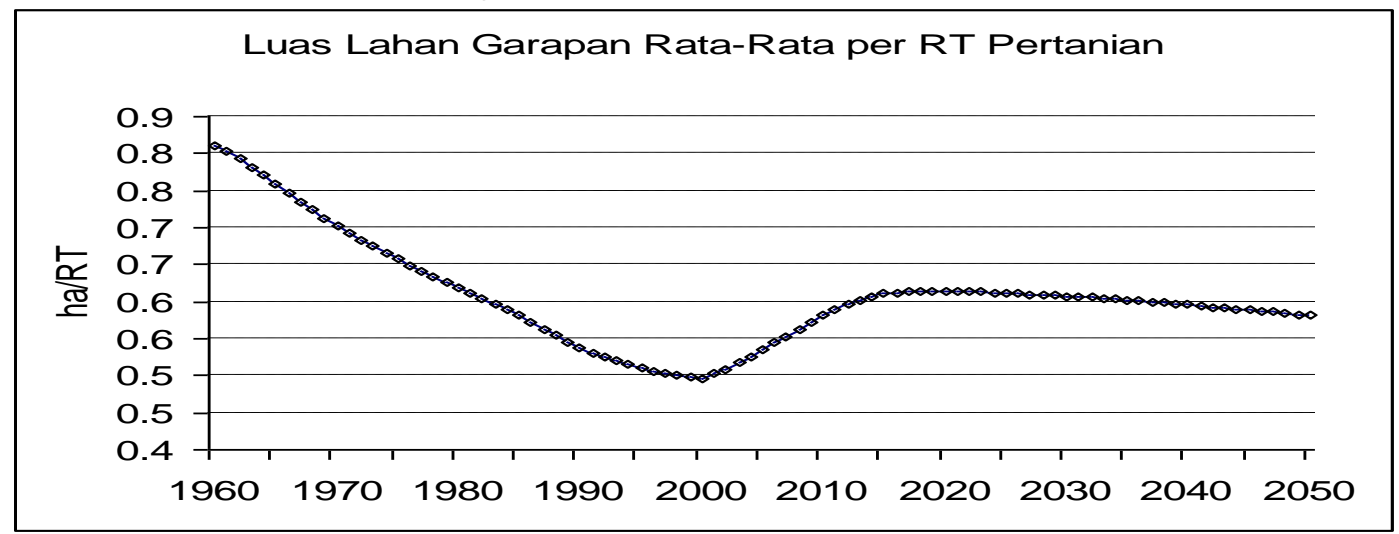

Gambar 8. Prediksi rata-rata luas lahan garapan per rumah tangga pertanian di Indonesia

\section{KESIMPULAN}

Dengan indeks diversifikasi pertanian tanaman yang sangat berbeda-beda, dapat disimpulkan bahwa perkembangan komersialisasi pertanian sebagai tanda berjalannya proses transformasi pertanian sangat beragam. Sebagian propinsi mempunyai derajat diversifikasi pertanian yang rendah. Pada propinsi-propinsi tersebut komersialisasi telah berjalan lancar. Pola ekonomi para petaninya telah bergeser dari pertanian subsisten ke pertanian komersial. Pembangunan pertanian di propinsi-propinsi tersebut telah masuk pada proses perkembangan tranformasi tahap lanjut. Namun sebagian propinsi-propinsi masih mempunyai indeks diversifikasi pertanian yang tinggi, komersialisasi masih belum berkembang baik. Bagi propinsi diluar Pulau Jawa, hal tersebut disebabkan karena keterbatasan infrastruktur, terisolir, atau hal lainnya, sehingga akses perdagangan dengan daerah luar propinsinya kurang lancar. Pada propinsi di pulau Jawa, hal tersebut diduga karena masih banyaknya pertanian subsisten, sehingga menghambat perkembangan komersialisasi pertanian, tetapi bisa juga karena cocoknya daerah 
tersebut ditanami berbagai jenis tanaman pangan. Dari kondisi ini dapat diketahui bahwa pembangunan pertanian belum merata di setiap propinsi di Indonesia.

Perkembangan komersialisasi pertanian memang diprediksi akan meningkat, tetapi peningkatan tersebut bukan karena perpindahan pertanian dari pola subsisten, namun karena adanya peningkatan rumah tangga pertanian total. Dengan demikian peningkatan pendapatan masyarakat tani tidak terjadi.

Untuk pemerataan pembangunan pertanian, maka direkomendasikan pembangunan sarana dan prasarana pertanian di sebagian wilayah khususnya wilayah yang jauh dan terisolir, mulai ditingkatkan. Sementara faktor-faktor penghambat keberlangsungan kegiatan komersialisasi, seperti penguasaan lahan yang sempit yang menyebabkan semakin berkembangnya pertanian subsisten khususnya di pulau Jawa, dapat dikurangi melalui reformasi pertanahan. Kebijakan reformasi pertanahan (Undang-Undang Land Reform) baik No. 1 tahun 58 tentang Penghapusan Tanah Partikelir, atau No 56 tahun 1960 tentang Penetapan Luas Tanah Pertanian apabila dijalankan dapat menjadi salah satu solusi agar petani keluar dari pola subsisten karena dapat memproduski tanaman pangan melebihi kebutuhan hidupnya. Kebijakan reformasi pertanahan di beberapa negara telah terbukti sebagai bagian dari kesuksesan mereka dalam membangun ekonomi pertaniannya.

\section{Ucapan Terima Kasih}

Penulis mengucapkan terima kasih kepada Prof. Dr. Burhan Arief., Dr. Ir. Ronnie S. Natawidjaja, M.Sc., Dr. Amru Hydari Nazif, M.Sc., dan Dr Muhammad Tasrif, Ir., M.Sc., atas segala kontribusinya pada penelitian ini. Terima kasih pula penulis ucapkan kepada Lembaga Ilmu Pengetahuan Indonesia yang telah memfasilitasi jalannya penelitina ini.

\section{DAFTAR PUSTAKA}

Ban, Sung Huan. 1979. "Agricultural Growth in Korea" in Hayami, Y., V.W. Ruttan, and H.M. Southworth (Eds). Agricultural Growth in Japan, Taiwan, Korea, and the Philippines. The University Press of Hawaii. Honolulu. pp.90-116.

BPS. 1999. Statistik Indonesia 1998. Jakarta

BPS. Statistik Indonesia. Berbagai publikasi

BPS. 1973. Statistik Indonesia 1972. Jakarta

Hayami, Y., V.W. Ruttan. 1979. "Agricultural Growth in Four Countries" in Hayami, Y., V.W. Ruttan. H.M. Southworth. (Eds). Agricultural Growth in Japan, Taiwan, Korea, and the Philippines. The University Press of Hawaii. Honolulu.pp.3-26. 
Http://www.kmna.go.id/peraturan/uu/auu/auu.htm. 24/0704

Huffman W.B., and Evenson. R.E.,1997. Long-Run Structural and Productivity Change in U.S. Agriculture:Effect of Prices and Policies. Center Discussion Paper no. 773. Economic Growth Center Yale University. <http://www.econ.yale.edu/growth-pdf/cdp773.pdf> [10/03/02].

Johnston, B.F., P. Kilby. 1975. Agriculture \& Structural Transformation: Economic Strategies ini Late-Developing Countries. New York: Oxford University Press.

Kuncoro. M. 1997. Ekonomi Pembangunan: Teori, Masalah dan Kebijakan. UPP AMP YKPN. Yogyakarta

Kurosaki, T., 2001. Specialization and Diversification in Agricultural Transformation: The Case of West Punjab, 1900-1995. February 2001, IER Discussion Paper Series A No. 406. Hitotsubashi University. Melalui <http://www.ier.hit-u.ac.jp/ kurosaki/ punjab2.pdf> [10/23/02].

Kurosaki, T.,2002a. "Agriculture in India and Pakistan, 1900-95: A Futher Note". Economic and Political Weekly. July 27, 2002 (Vol.37, No.30):3149-3152. Melalui <http://www.ier.hitu.ac.jp/ kurosaki/epw0108.pdf> [10/23/02].

Kurosaki, T.,2002b. "Specialization and Diversification in Agricultural Transformation: The Case of West Punjab, 1903-1992". Forthcoming in American Journal Agricultural Economics. Melalui $<$ http://www.ier.hit-u.ac.jp/ kurosaki/punjab4.pdf>[10/23/02].

Lee, Teng-hui. Yueh-eh Chen,. 1979. "Agricultural Growth in Taiwan" in Hayami, Y., V.W. Ruttan, H.M. Southworth. (Eds). Agricultural Growth in Japan, Taiwan, Korea, and the Philippines. The University Press of Hawaii. Honolulu.pp.59-89

Pingali, P.L. 1997. "From Subsistence to Commercial Production Systems: The Transformation of Asian Agriculture". American Journal of Argricultural Economics 79 (May 1997):628-634. American Agricultural Economics Association.

Rosegrant, M.W., and Hazell. P.B.R., 2000. Transforming The Rural Asia Economy: The Unfinished Revolution. Oxford University Press (China) Ltd. Hongkong <http://www.adb.org/Documents/Books/Rural_Asia/Unfinished_Revolution/default.asp> [08/16/02].

Saparita, R. 2004. Model Transformasi Pertanian di Indonesia Menggunakan Pendekatan System Dynamics, Disertasi S3. Program Pascasarjana Universitas Padjadjaran. Tidak Dipublikasikan.

Timmer,C. Peter.1997. "Farmer and Markets: The Political Economy of New Paradigms". American Journal of Argricultural Economics Vol. 79 (May 1997) :pp.621-627. American Agricultural Economics Association.

Todaro, M.P. 2000. Pembangunan Ekonomi 1. Edisi ke-lima. Munandar, H. (pen). Bumi Aksara. Jakarta

Yamada, S., Y. Hayami. 1979. "Agricultural Growth in Japan, 1880-1970" in Hayami, Y., V.W. Ruttan, H.M. Southworth. (Eds). Agricultural Growth in Japan, Taiwan, Korea, and the Philippines. The University Press of Hawaii. Honolulu.pp.33-58. 